\title{
Rajoista ja niiden ylittämisestä
}

\author{
Lapsuus ja nuoruus muistelussa
}

Ulla Savolainen ja Riikka Taavetti

L apsuus ja nuoruus ovat lähes itsestään selviä muistelun, nostalgisoinnin ja myöhempien arviointien kohteita modernisoituneessa läntisessä maailmassa. Kasvanutta kiinnostusta lapsuuteen ja nuoruuteen aikuisuudesta erillisinä elämänvaiheina on pidetty erityisesti 1700-luvun lopulla käynnistyneeseen modernisaatiokehitykseen liittyvänä ilmiönä. Lapsuuden merkityksen kasvu on nähty osana laajempaa historiallista prosessia, johon kytkeytyy myös yksilöllisyyden ja yksityisyyden ideoiden painoarvon nousu sekä lisääntyneet liikkuvuuden mahdollisuudet niin sosiaalisesti kuin paikkojen välillä. (Ks. Ahlbeck et al. 2017, 2-6.) Psykoanalyysin ideoiden yleistyttyä osaksi populaaria ajattelua lapsuuden kokemukset mielletään myös keskeisinä aikuisen elämän muokkaajina. Niin lapsuuteen kuin nuoruuteenkin liitetään lisäksi vakiintuneita kulttuurisia käsityksiä viattomuudesta, huolettomuudesta ja onnellisuudesta, mutta toisaalta myös keskenkasvuisuudesta, kehittymättömyydestä ja jopa pahuudesta. Omaelämäkerroissa omasta elämästä kertominen aloitetaan tyypillisesti lapsuudesta ja nuoruusmuistoja pidetään usein erityisen elävinä ja elinvoimaisina.

Mutta miten lapsuuteen ja nuoruuteen liittyviä muistoja tuotetaan ja tutkitaan? Mitä erityistä on juuri lapsuuden ja nuoruuden muistamisessa? Teemakokonaisuutemme artikkelit ja katsaukset paneutuvat lapsuuden ja nuoruuden esityksiin moninaisissa muisteluaineistoissa sekä pureutuvat muistelun, muistamisen ja muistin tutkimuksen monitieteisiin metodologisiin kysymyksiin niin kulttuurintutkimuksen kuin historiatieteidenkin näkökulmista. Teemakokonaisuuden artikkeleissa ja katsauksissa analysoidaan muistelukirjoitusten kokoelmia, muistitietohaastatteluja, muistelmakirjallisuutta sekä journalistisia aineistoja. Niissä pohditaan yksilön muistelun yhteyttä yhteiskunnalliseen keskusteluun, politiikkaan ja ideologioihin sekä henkilökohtaisten muistojen yhteyttä jaettuihin kulttuurisiin käsityksiin menneisyyden ja nykyisyyden suhteesta. Kirjoitukset käsittelevät myös omakohtaisen muistelun ja kaunokirjallisuuden liukuvia rajoja.

Teemanumeron kirjoituksia yhdistää se, että niiden käsittelemissä aineistoissa lapsuudesta ja nuoruudesta kerrotaan aikuisuudesta käsin ja aikuisen näkökulmasta. Tällöin lapsuuden ja nuoruuden kokemukset peilautuvat omien myöhempien elämänkokemusten sekä mahdollisten omien vanhemmuuden kokemusten kautta. Muistoja myös tuotetaan suhteessa muuttuneisiin yhteiskunnallisiin ja kulttuurisiin käsityksiin lapsuudesta ja nuoruudesta. Teemakokonaisuus tarjoaa moninaisia näkökulmia siihen, miten lapsuus ja nuoruus 
merkityksellistyvät eri asiayhteyksissä ja ilmaisun muodoissa, kun niitä tarkastellaan aikuisuuden rajan takaa, ajallisen matkan päästä.

\section{Lapsuus ja nuoruus muistitietotutkimuksessa ja nuorisotutkimuksessa}

Teemakokonaisuuden kirjoittajien edustamien tieteenalojen välisistä eroista sekä artikkeleiden ja katsausten varsin erilaisista tutkimusaiheista huolimatta teemakokonaisuuden kirjoitukset kytkeytyvät suomalaisen muistitietotutkimuksen monipuoliseen kenttään. Suomalaiselle ja laajemminkin pohjoismais-balttialaiselle muistitietotutkimukselle leimallisia piirteitä ovat monipuolisten tutkimusaineistojen hyödyntäminen sekä metodologisten lähestymistapojen, erityisesti kansainvälisten oral history - ja (cultural) memory studies -tutkimussuuntausten yhdistäminen ja soveltaminen. (Suomalaisesta muistitietotutkimuksesta ks. esim. Heimo 2016; Fingerroos ja Haanpää 2012; Fingerroos, Haanpää, Heimo ja Peltonen 2006, oral history -suuntauksesta ja muistitietotutkimuksesta myös Taavetti 2018, 52-56.) Näiden lähestymistapojen yhdistämistä voidaan pitää jossain määrin poikkeuksellisena.

Kansainvälisesti katsoen oral history - ja memory studies -tutkimussuunnat ovat pysytelleet etäällä toisistaan muun muassa siksi, että niiden (tieteen)historialliset taustat, tutkimusaineistot ja osin näkökulmatkin ovat erilaisia. Oral history -tutkimuksen aineistoina ovat olleet lähes yksinomaan haastatteluaineistot, suullinen historia, kun taas memory studies -suuntauksen tutkimusaineistot ja -kohteet ovat moninaiset. Memory studies -tutkimusten kohteet ulottuvat institutionaalisesta muistamisesta yksilöiden muistikäytänteisiin, museoista ja julkisista muistomerkeistä yksityisiin valokuviin ja muistoesineisiin sekä kirjallisuudesta ja taiteesta muistin välittymisen kysymyksiin ja psykologian ja kognitiotieteen kokeellisiin asetelmiin (memory studies -suuntauksesta ks. esim. Erll 2011). Tutkimussuuntauksia yhdistää kuitenkin se, että ne ovat kiinnostuneita menneisyydelle nykyhetkessä annetuista merkityksistä ja muistamisen sosiaalisista aspekteista. (Tutkimussuuntien eroista ja yhtäläisyyksistä ks. esim. Hamilton ja Shopes 2008; Heimo 2010, 37-39; Savolainen 2017, 29-32; 2018, 5-6.)

Suomalaisessa muistitietotutkimuksessa lapsuuden ja nuoruuden muistelua on tutkittu jonkin verran (esim. Korkiakangas 1996; Tuomaala 2004; Savolainen 2015; myös Salmi-Niklander 2004). Sen sijaan suomalaisella nuorisotutkimuksen kentällä nuoruuden muistelu ei ole ollut toistaiseksi erityisen laajan kiinnostuksen kohteena. Nuoruuden omaelämäkerrallisia kuvauksia käsittelevän Nuoruuden sukupolvet -artikkelikokoelman toimittajat Kaisa Vehkalahti ja Leena Suurpää (2014) kuvaavat, miten historioivan tutkimuksen piirissä nuoria on käsitelty useimmiten instituutioiden, ensisijaisesti koulun, kehyksissä, mutta tämän tutkimussuunnan rinnalla kulkee toinen juonne, jossa nuoruutta on käsitelty populaarikulttuurin ja vapaa-ajan historian kautta (uudemmista tämän suuntauksen tutkimuksista ks. esim. Poikolainen 2015; Tormulainen 2018). Vehkalahti ja Suurpää kommentoivat myös, että historiallinen ja nykynuoruutta koskeva tutkimus ovat olleet pitkälti erillisiä. Katsommekin, että muistitietotutkimus tarjoaa yhden tavan kyseenalaistaa menneen ja nykyhetken erillisyys. Muistitietotutkimuksen keinoin voidaan käsitellä yhtäältä sitä, miten mennyt on läsnä nykypäivässä, ja toisaalta sitä, miten nykyisyys tuottaa menneisyyttä muistelussa.

\section{Yhteiskunnallinen aika}

Se, ettei nuoruuden muistelua ole tutkittu kovin runsaasti suomalaisen nuorisotutkimuksen kehyksissä, ei kuitenkaan tarkoita, etteikö nuoruuden muistelu olisi näkyvästi esillä 
julkisuudessa. Teemanumeron ensimmäisessä artikkelissa "'Hei me itse nyt tehdään!' - muistoja nuoruudesta teinikuntatoiminnassa ja nuortaistolaisessa liikkeessä" Essi Jouhki ja Liisa Lalu paneutuvat julkisuudessa paljon käsiteltyyn aiheeseen, 1960-luvun lopun ja 1970-luvun alun nuorisoliikehdinnän muistamiseen. He analysoivat, miten julkisuudessa nostalgisoitua, kauhisteltua ja ylipolitisoituneeksikin kutsuttua aikaa muistellaan nyt, 2010-luvulla, haastatteluissa ja muistelukirjoituksissa. Jouhkin ja Lalun artikkelissa muistitietotutkimuksen näkökulmat menneisyyden ja nykyisyyden dialogiseen suhteeseen yhdistyvät nuoruuden hahmottamiseen historiallisesti rakentuneiden yhteiskunnallisten suhteiden kautta.

Jouhkin ja Lalun analyysi osoittaa, että teinikuntatoiminnan ja taistolaisliikkeen muistelussa yhteisöllisyyden ja yhteistoiminnan merkitykset nousevat esiin politiikan ohella, joskus sitä tärkeämpinäkin. Muistelussa kuvatut yhteisöt ulottuvat paikallistasolta valtakunnalliselle ja jopa globaalille tasolle, koko maailman nousevaan nuorisoon. Samalla yhteisöllisyyden muistelu voi olla tapa väistää myöhemmin kiusallisiksi muuttuneita poliittisen toiminnan vaiheita omassa henkilöhistoriassa. Toisaalta Jouhkin ja Lalun tutkimuksessa näkyy, miten oman nuoruuden historiallista kontekstia, "ajan henkeä", käytetään muistelussa kuvaamaan ja selittämään menneisyyttä ja omia toimia. Erityisesti teinikuntien ja taistolaisuuden kaltaisten paljon muisteltujen ja sukupolvi-ilmiön asemaan nostettujen liikkeiden kohdalla näkyy myös se, kuinka muistelu on myös osaltaan muokannut "ajan henkeä" kerrottuna ja nykypäivässä rakentuneena menneisyyden ilmiönä.

Myös Veera Mollin ja Laika Nevalaisen artikkeli "'Silloin oli ihan normaalia, että lapset kulkivat itsekseen tarhaan ja sieltä kotiin': Muistitietoaineistojen itsenäiset kaupunkilaislapset" paneutuu julkisuudessa keskusteltuun aiheeseen, lasten omatoimiseen liikkumiseen kaupunkitilassa. Kirjoittajat tarkastelevat kirjoitettujen muisteluaineistojen avulla, miten lapsuuden Helsingistä ja siellä liikkumisesta kerrotaan aikuisuudessa. Mollin ja Nevalaisen tutkimuksessa painottuvat lasten toimijuuden näkökulmat: kirjoittajat pohtivat kaupunkitilaa, liikkumisen mahdollisuuksia sekä liikkumiselle asetettuja rajoituksia lapsen näkökulmasta käsin. Kuten kirjoittajat toteavat, muistelukirjoituksissa lapsuuden kokemuksia tarkastellaan väistämättä aikuistuneen muistelijan nykypäivästä käsin, myöhempien elämänkokemusten sekä lapsuutta koskevien kulttuuristen ja yhteiskunnallisten käsitysten muovaamasta näkökulmasta. Siksi muisteluaineisto tarjoaa mielenkiintoisen tilaisuuden tarkastella myös fyysisen kaupunkitilan muuttumisen vaikutuksia sekä liikkumisen muuttuneita merkityksiä. Mollin ja Nevalaisen artikkeli kytkeytyy lapsuuden historian tutkimuksen sekä kaupunkimaantieteen piirissä käytyihin keskusteluihin ja tuo niihin muistitietotutkimukseen paikantuvan metodologisen näkökulman.

\section{Rajojen ylityksiä}

Lapsuuden ja aikuisuuden välisen rajan lisäksi teemakokonaisuuden artikkeleissa tarkastellaan myös toisenlaisia rajanylityksiä. Ulla Savolainen analysoi artikkelissaan "Lapsuuden loppu ja Inkerinmaa Juhani Konkan muistelmateoksissa: Kasvu, ylirajaisuus ja kahden nykyisyyden muisti" inkeriläissyntyisen Konkan kahta muistelmateosta kulttuurisen muistin näkökulmasta. Teoksissa Konkka kuvaa lapsuuttaan ja nuoruuttaan Inkerissä sekä siirtymistään Suomeen. Artikkelissaan Savolainen tarkastelee kasvun teemaa ja ylirajaisuutta lukemalla muistelmia suhteessa modernin omaelämäkerran ja kehitysromaanin lajeihin. Savolaisen luenta Konkan eri aikoina ilmestyneistä teoksista tarjoaa myös näkökulman siihen, millä 
tavalla lapsuuden- ja nuoruudenkokemuksia muistetaan ja artikuloidaan erilaisissa historiallisissa ja yhteiskunnallisissa tilanteissa.

Myös Kristiina Silvanin katsaus "Haastatteluja aika- ja kulttuurirajojen yli Valko-Venäjän kommunistisen järjestönuoruuden muistelukontekstissa" keskittyy ylirajaisuuden teemoihin. Silvan pohtii kirjoituksessaan, millaisia kysymyksiä muistitietohaastattelussa nousee esiin, kun haastattelijaa ja haastateltavaa erottavat kieli- ja kulttuurirajat. Silvanin haastatteluiden teemana oli Komsomolin eli Neuvostoliiton kommunistisen puolueen nuorisojärjestön sekä sen piirissä eletyn opiskelija-arjen muistaminen Valko-Venäjällä. Silvanin tutkimuksessa menneisyyden ja nykyisyyden välinen merkittävä historiallinen muutos, eli Neuvostoliiton hajoaminen ja itsenäisen Valko-Venäjän syntyminen, vaikuttaa Komsomol-nuoruuden muistamiseen sekä vuorovaikutukseen haastattelijan ja haastateltavan välillä. Silvan pohtii katsauksessaan sitä, miten haastatteluissa läsnä olevat erot, kuten sukupuoli ja ikä, merkityksellistyvät uudelleen kulttuurierojen kautta.

Teemakokonaisuuden päättävä Riikka Taavetin katsaus "Sukupolven käsite ja sateenkaarevan nuoruuden muistaminen" pureutuu sukupolven käsitteeseen, jonka analyyttinen käsittely ja metodologinen hyödyntäminen on ollut toistaiseksi vähäistä suomalaisessa muistitietotutkimuksessa. Sukupolven käsite on keskeinen nuoruudentutkimuksen, mutta ennen kaikkea nuoruuden muistamisen tutkimuksen kannalta. Kuten Vehkalahti ja Suurpää (2014) toteavat, yhteiskunnalliset sukupolvet nimetään usein nuoruudenaikaisten kokemusten ja populaarikulttuurin ilmiöiden mukaan (perheiden ja yhteiskuntien sukupolvista ks. myös esim. Häkkinen 2013; Suomen historian sukupolvista ks. Virtanen 2003). Toisaalta nuoruuden populaarikulttuurin ilmiöt voivat olla muistelun apuväline, keino tuoda samanaikaisen nuoruuden eläneitä yhteen ja rakentaa muistoja yhteiseen menneisyyteen liitettävien kulttuuriviitteiden avulla (esim. Tormulainen 2018). Katsauksessaan Taavetti käsittelee sateenkaarinuoruuden muistamista ja queer-teoreettisia näkökulmia aikaan sekä pohtii näiden avulla, miten sukupolven käsite monimutkaistuu entisestään, kun sitä tarkastellaan normeja haastavan seksuaalisuuden ja sukupuolen näkökulmista.

\section{Moninaistuvia nuoruuden ja lapsuuden tulkintoja}

Teemakokonaisuus lapsuuden ja nuoruuden muistamisesta ja kertomisesta valottaa monitieteisestä näkökulmasta kulttuuristen kertomusten ja tulkintakehysten vuorovaikutusta omakohtaisten menneisyyden esitysten kanssa. Yhdessä teemakokonaisuuden kirjoitukset tarjoavat aineksia uusille tutkimuksille, jotka haluavat ymmärtää ja problematisoida esimerkiksi nostalgisoituja tai stigmatisoituja menneisyyskuvia sekä sukupolvittaista tai aikakausittaista tapaa hahmottaa historiaa. Toivomme, että teemakokonaisuutemme toimii keskustelunavauksena niin tutkimuksille lapsuuden ja nuoruuden rakentumisesta muistelussa ja kerronnassa kuin menneisyyden ja nykyisyyden välisen suhteen pohtimiselle laajemminkin. 


\section{Kirjallisuus}

Ahlbeck, Jutta, Päivi Lappalainen, Kati Launis ja Kirsi Tuohela. 2017. "Introduction: Child Figures as Fragile Subjects." Teoksessa Childhood, Literature and Science: Fragile Subjects, toimittaneet Jutta Ahlbeck, Päivi Lappalainen, Kati Launis ja Kirsi Tuohela, 1-19. Milton: Taylor \& Francis Group.

Erll, Astrid. 2011. Memory in Culture. Basignstoke, Houndmills: Palgrave Macmillan. https:// doi.org/10.1057/9780230321670.

Fingerroos, Outi ja Riina Haanpää. 2012. "Fundamental Issues in Finnish Oral History Studies." Oral History 40(2): 81-92.

Fingerroos, Outi, Riina Haanpää, Anne Heimo ja Ulla-Maija Peltonen (toimittaneet). 2006. Muistitietotutkimus: Metodologisia kysymyksiä. Helsinki: Suomalaisen Kirjallisuuden Seura.

Hamilton, Paula ja Linda Shopes. 2008. "Introduction: Building partnership between oral history and memory studies." Teoksessa Oral History and Public Memories, toimittaneet Paula Hamilton ja Linda Shopes, vii-xvii. Philadelphia:Temple University Press.

Heimo, Anne. 2010. Kapina Sammatissa: Vuoden 1918 paikalliset tulkinnat osana historian yhteiskunnallisen rakentamisen prosessia. Helsinki: Suomalaisen Kirjallisuuden Seura.

Heimo, Anne. 2016. "Nordic-Baltic Oral History on the Move." Oral History 44(2): 37-58.

Häkkinen, Antti. 2013. "Suomalaiset sukupolvet, elämänkulku ja historia: Sukupolvesta sukupolveen." Teoksessa Sosiaalinen albumi: Elämäntavat sukupolvien murroksissa, toimittaneet Antti Häkkinen, Anne Puuronen, Mikko Salasuo ja Anni Ojajärvi, 21-55. Helsinki: Nuorisotutkimusseura.

Korkiakangas, Pirjo. 1996. Muistoista rakentuva lapsuus: Agraarinen perintö lapsuuden työnteon ja leikkien muistelussa. Helsinki: Suomen muinaismuistoyhdistys.

Poikolainen, Janne. 2015. Musiikkifanius ja modernisoituva nuoruus: Populaarimusiikin ihailijakulttuurin rakentuminen Suomessa 1950-luvulta 1970-luvun alkuun. Helsinki: Nuorisotutkimusseura.

Salmi-Niklander, Kirsti. 2004. Itsekasvatusta ja kapinaa: Tutkimus Karkkilan työläisnuorten kirjoittavasta keskusteluyhteisöstä 1910- ja 1920-luvuilla. Helsinki: Suomalaisen Kirjallisuuden Seura.

Savolainen, Ulla. 2015. Muisteltu ja kirjoitettu evakkomatka: Tutkimus evakkolapsuuden muistelukerronnan poetiikasta. Joensuu: Suomen Kansantietouden Tutkijain Seura.

Savolainen, Ulla. 2017. "Tellability, frame and silence:The emergence of internment memory." Narrative Inquiry 27(1): 24-46. https://doi.org/10.1075/ni.27.1.02sav.

Savolainen, Ulla. 2018. "Points and Poetics of Memory: (Retrospective) Justice in Oral History Interviews of Former Internees." Memory Studies. Julkaistu ensin verkossa 22.10.2018. https://doi.org/10.1177/1750698018806946.

Taavetti, Riikka. 2018. Queer Politics of Memory: Undisciplined Sexualities as Glimpses and Fragments in Finnish and Estonian Pasts. Helsinki: Helsingin yliopisto. http://urn.fi/ URN:ISBN:978-951-51-3330-4.

Tormulainen, Aino. 2018. Tyttöenergialla kasvaneet: Postfeministisen populaarikulttuuriilmiön yhdessä muistellut merkitykset. Helsinki: Nuorisotutkimusseura. 
Tuomaala, Saara. 2004. Työtätekevistä käsistä puhtaiksi ja kirjoittaviksi: Suomalaisen oppivelvollisuuskoulun ja maalaislasten kohtaaminen 1921-1939. Helsinki: Suomalaisen Kirjallisuuden Seura.

Vehkalahti, Kaisa ja Leena Suurpää. 2014. "Johdanto: Nuoruus, sukupolvet ja oman elämän kirjoittaminen." Teoksessa Nuoruuden sukupolvet: Monitieteisiä näkökulmia nuoruuteen eilen ja tänään, toimittaneet Kaisa Vehkalahti ja Leena Suurpää, 5-29. Helsinki: Nuorisotutkimusseura.

Virtanen, Matti. 2003. "Nuoren Suomen traditio sukupolvien ketjuna."Teoksessa Nuoruuden vuosisata: Suomalaisen nuorison historiaa, toimittaneet Sinikka Aapola ja Mervi Kaarninen, 35-65. Helsinki: Suomalaisen Kirjallisuuden Seura.

Filosofian tohtori Ulla Savolainen työskentelee Suomen Akatemian tutkijatohtorina Helsingin yliopistossa folkloristiikan oppiaineessa. "Memory Unchained" -hankkeessaan hän tutkii inkeriläisten kokemuksia käsittelevää kirjallisuutta kulttuurisen muistin näkökulmasta.

Valtiotieteiden tohtori Riikka Taavetti työskentelee Helsingin yliopistossa poliittisen historian tutkijana ja tutkii queer-muistitietoa ja muistin politiikkaa Suomessa ja Virossa. 